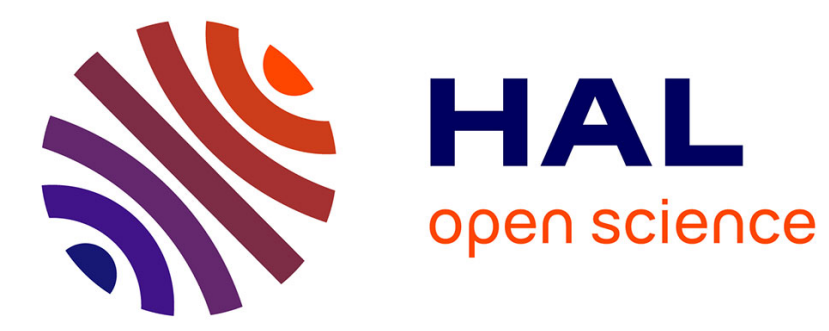

\title{
HIGH QUALITY OXIDES FOR LARGE AREA DISPLAYS
}

\author{
L. Johnson, M. Saunders, D. Meakin
}

\section{To cite this version:}

L. Johnson, M. Saunders, D. Meakin. HIGH QUALITY OXIDES FOR LARGE AREA DISPLAYS. Journal de Physique IV Proceedings, 1991, 02 (C2), pp.C2-505-C2-505. 10.1051/jp4:1991262 . jpa00249852

\section{HAL Id: jpa-00249852 https://hal.science/jpa-00249852}

Submitted on 1 Jan 1991

HAL is a multi-disciplinary open access archive for the deposit and dissemination of scientific research documents, whether they are published or not. The documents may come from teaching and research institutions in France or abroad, or from public or private research centers.
L'archive ouverte pluridisciplinaire HAL, est destinée au dépôt et à la diffusion de documents scientifiques de niveau recherche, publiés ou non, émanant des établissements d'enseignement et de recherche français ou étrangers, des laboratoires publics ou privés. 
Colloque C2, suppl. au Journal de Physique II, Vol. 1, septembre 1991

\title{
HIGH QUALITY OXIDES FOR LARGE AREA DISPLAYS
}

\author{
L.M. JOHNSON, M. SAUNDERS and D.B. MEAKIN \\ Leybold AG, Siemensstrasse 100, D-8755 Alzenau, Germany
}

\begin{abstract}
Great interest has been shown over recent years in the development of large area polysilicon active matrix displays. Availability of a reliable process for gate oxide formation over large area has proved a major barrier, despite significant advances in similar wafer processing systems.
\end{abstract}

A system has been developed for deposition of low temperature oxides on large area (up to $14 \times 14$ inches) glass substrates.

The characteristics of the deposited films have been studied and the suitability of the process and equipment for large area displays will be demonstrated. 